\title{
Cassava cultivars selected or developed from interspecific hybrids and periclinal chimeras
}

\author{
N.M.A. Nassar \\ Departamento de Genética e Morfologia, Universidade de Brasília, Brasília, DF, \\ Brasil \\ Corresponding author: N.M.A. Nassar \\ E-mail: nagibnassar@geneconserve.pro.br \\ Genet. Mol. Res. 18 (3): gmr18385 \\ Received June 07, 2019 \\ Accepted July 27, 2019 \\ Published August 14, 2019 \\ DOI http://dx.doi.org/10.4238/gmr18385
}

\begin{abstract}
Through use of interspecific hybridization, and in some cases followed by polyploidization, cassava cultivars combining various desirable characteristics have been developed in Brazil. These range from high protein content and increased essential amino acids to tolerance to drought. Some cultivars have highly apomictic behavior. Others show tolerance to bacterial diseases and insect pests. Selection from crosses with indigenous cultivars has led to obtaining varieties with high beta carotene content and excellent palatability. Periclinal chimeras were successfully synthesized and gave very high productivity. Ten outstanding genotypes resulting from this ongoing selection and breeding program are part of the University of Brasilia living Manihot collection and are reviewed here.
\end{abstract}

Key words: Interspecific hybridization; Polyploidization; Apomixis; Protein and essential amino acid content; Beta carotene; Periclinal chimera

\section{INTRODUCTION}

Over the years, since 1974, wild cassava has been collected from Brazil, the rest of South America and from Central America (Nassar, 1977). The specimens were grown in a living collection at the Universidade de Brasilia, to screen for useful genes and have been hybridized with cultigens. Interspecific hybrids that were functionally sterile were polyploidized to restore fertility (Nassar et al. 1996; Nassar, 2008: Nassar and Ortiz, 2008). Since 1978, we have bred cassava cultivars from this broad genetic base for many characters (Nassar and Collevatti, 2008), Indigenous cultivars were also collected and screened. Using this stock, we were able to develop 
high carotene content cultivars. Periclinal chimera were synthesized and from them we developed very highly productive cultivars that attained up to four times normal yields. This new technique for breeding cassava and perennial crops overcomes the need to wait long periods for flowering and gene segregation. Using interspecific hybridization, followed by polyploidization, we were able to transfer useful genes and establish them in progeny. Some of the most striking features were obtained by producing apomictic clones from interspecific hybridization, followed by polyploidization. Resistance to mealy bug, high protein content and increased essential amino acids were also attained (Nassar and Ortiz, 2010, Nassar and Souza, 2007). The use of periclinal chimeras to combine traits opened a new line of research in breeding perennial crops. Here we describe some of the cassava cultivars developed by these techniques; they are described morphologically based on parameters recommended by Rogers and Appan (1973) and Rogers and Fleming (1973).

\section{UnB 310}

UnB 310 was selected from progeny of ICB 300, a hybrid between cassava and Manihot oligantha (Nassar and Dorea, 1982). It is a triploid plant with chromosome number $2 \mathrm{n}=54$. This variety has extremely vigorous vegetative growth, with high productivity, reaching $25 \mathrm{~kg}$ of tubers per plant in the third year after planting. It combines high productivity with a very low toxicity of $13 \mathrm{mg} \mathrm{HCN} \mathrm{/} \mathrm{kg}$ of cassava root. Similar to its ancestor, ICB 300, it is rich in antioxidant lutein (Nassar et al., 2007). This cultivar grows as a semi erect shrub reaching $3 \mathrm{~m}$ tall, with 3 - 4 erect branches. The stems are glabrous; young stems are light green, turning light brown when mature. They produce moderate amounts of latex. Leaves are membranaceous on both faces. The fruit is globose, with small and purplish pigmented wings. Roots are numerous and cylindrical (Figure 1).

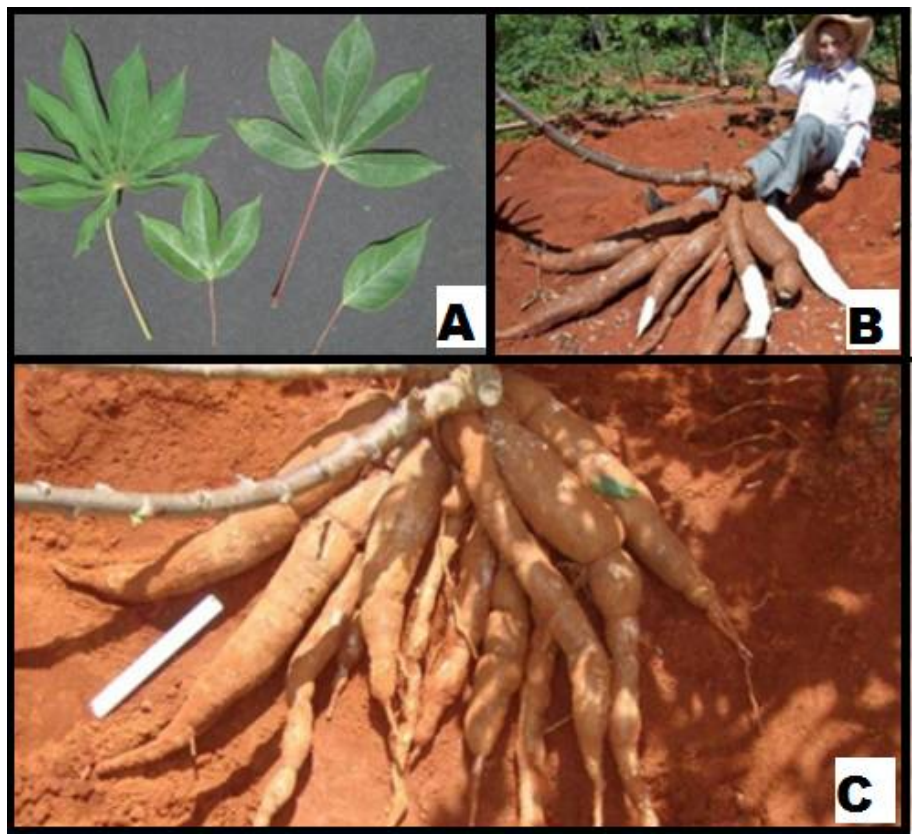

Figure 1. Manihot esculenta cultivar UnB 310. (A) Membranaceous leaves shown from above and below. (B) and (C) Root morphology. 


\section{UnB 307-22}

A cassava cultivar selected from Manihot glaziovii X cassava hybrids. It produces $8-10 \mathrm{~kg}$ of roots after one year. This plant is facultatively apomictic, producing $20-25 \%$ polyembryonic ovules. The roots resist post-harvest deterioration (Nassar, 1996). It is grown by farmers in rural areas of the Federal District: Sao Sebastiao, Gama and also by settlements de Sao Joao de Alianca and Sao Gabriel, Goias.

It is a erect and robust shrub, ca. 2.5 - 3 m tall, with 1 - 3 erect stems. Young stems are purple and become grey-brown when mature (Figure 2), Leaves are membranaceous; petioles are cylindrical, reddish to green, decumbent when mature, and finely pubescent; roots are cylindrical, vigorous and numerous (Figure 2), ca. 70 $85 \mathrm{~cm}$ long and $4-7 \mathrm{~cm}$ in diameter, with a small peduncle. Roots are resistant to postharvest deterioration. The low HCN content permits use for cooking.

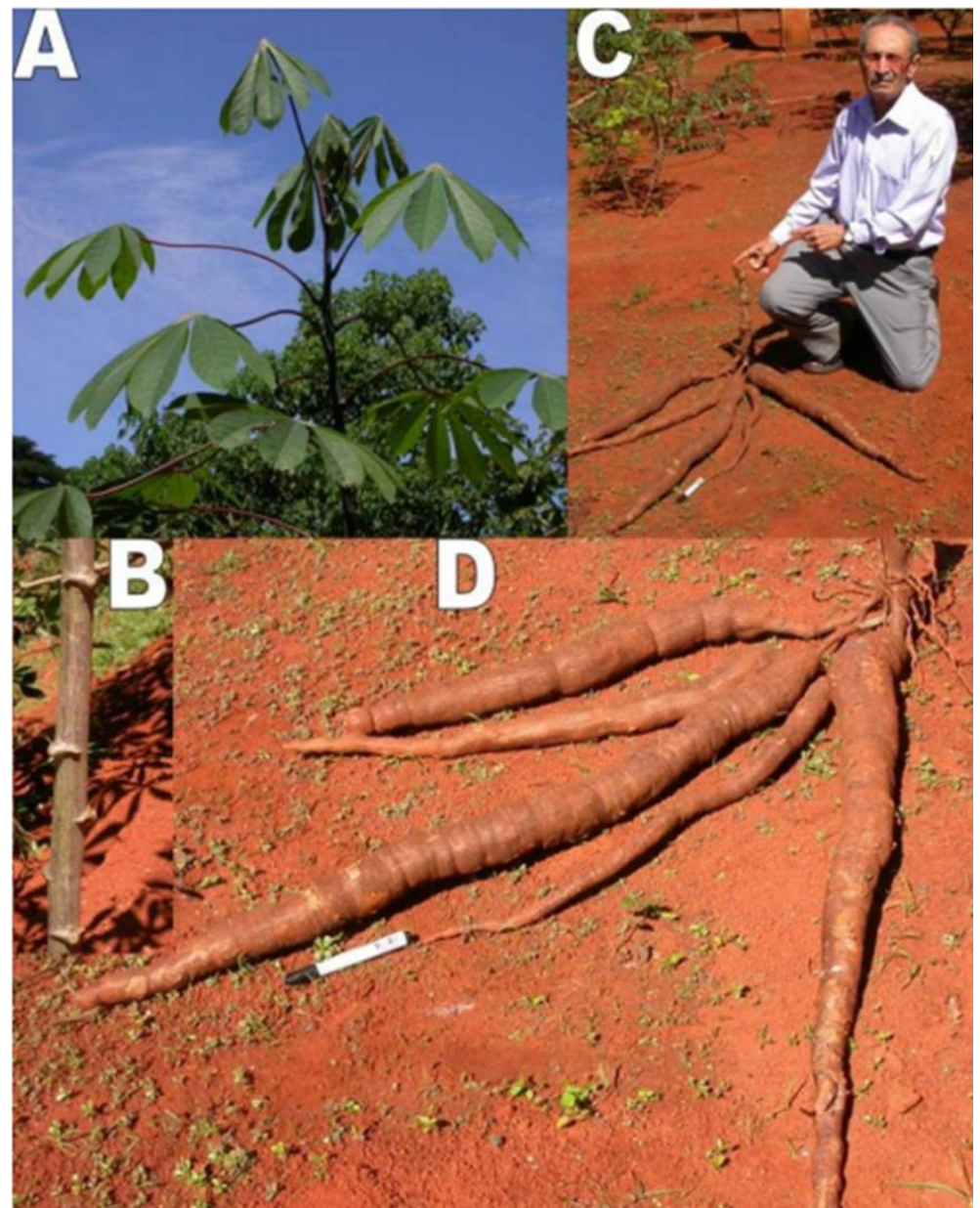

Figure 2. UnB 307-22 morphology characterization. (A) Leaf morphology; (B) Stem nodes; (C) and (D) Root morphology. 


\section{UnB 220}

Cassava variety UnB 220 is an interspecific hybrid between Manihot fortalezensis and cassava (Nassar, 2008; Nassar et al., 2010a). It is very productive, producing $8-10 \mathrm{~kg}$ roots when planted at $70 \times 70 \mathrm{~cm}$, very tolerant to drought with vigorous growth and is recommended for semi-arid regions. This variety has long fibrous roots, allowing it to obtain subterranean water. It is recommended for semiarid regions in Brazil, particularly in Ceara state where its progenitor $M$. fortalezensis was collected. It is a robust semi-erect shrub, ca. 4 - $5 \mathrm{~m}$ tall (Figure 3). Stems are di-trichotomous and decumbent; young stems are reddish-purple, changing to green and reddish brown at maturity; stems have small petiole scars, leaves are membranaceous and alternate (Figure 3), roots, are long or small, cylindrical and numerous (Figure 3), ca. 20 - 60 (and up to 160) $\mathrm{cm}$ long and $4-6 \mathrm{~cm}$ in diameter, with a small peduncle, usually without constrictions.

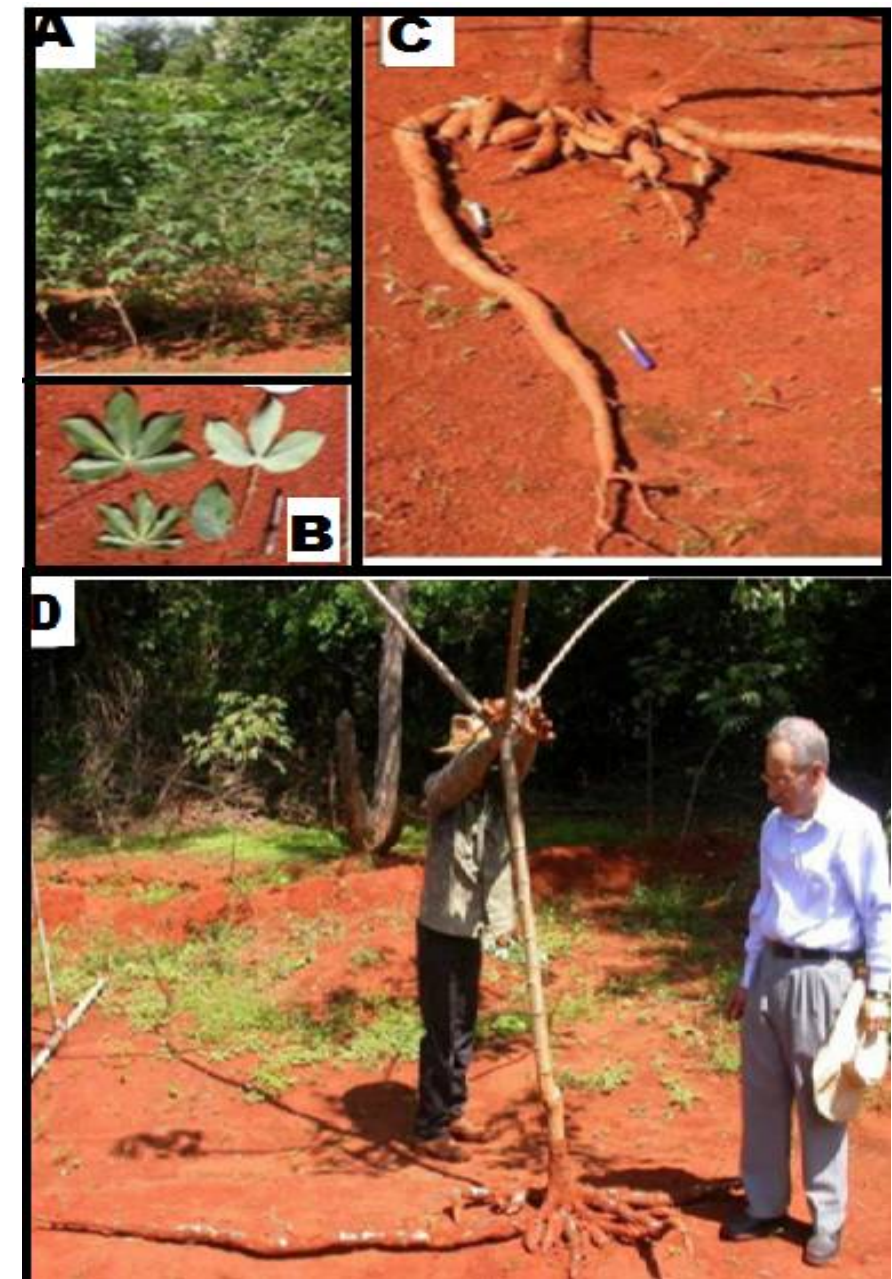

Figure 3. UnB 220. (A) Morphology of whole plants; (B) Leaf morphology and size; (C) and (D) Root size and morphology. 


\section{UnB 031}

Cassava cultivar UnB 031 was selected from the progeny of an interspecific hybrid of Manihot dichotoma with cassava. It is already very productive in the second year after planting, under Federal District (Brasilia) conditions. Roots are very tolerant to post harvest deterioration and are used to produce flour.

It is a semi-erect shrub, ca. $2-2.5 \mathrm{~m}$ tall. There is a single central stem, $1.5-2.5 \mathrm{~cm}$ in diameter (Figure 4); young stems are purple to reddish with prominent petiole scar nodes (Figure 4). Leaves are membranaceous and glabrous on both faces; Fruit is globose and glabrous, with small and purplish tinged wings; roots are long, cylindrical, and numerous (Figure 4), ca. 30 - 65 (up to 80 ) $\mathrm{cm}$ long and $4-6 \mathrm{~cm}$ in diameter.

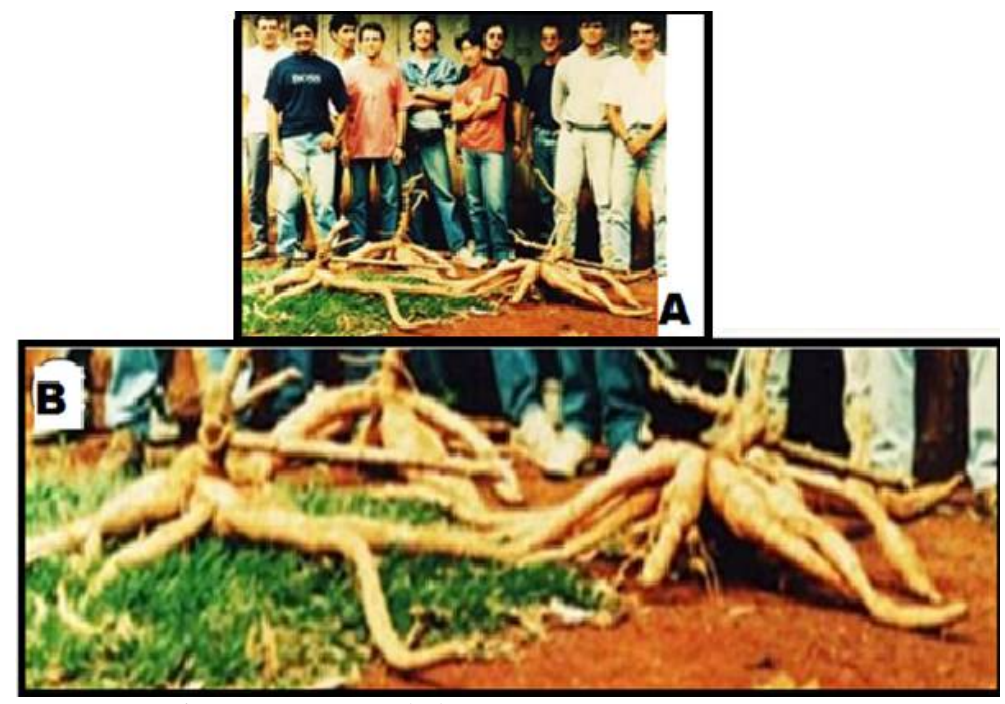

Figure 4. UnB 31. (A) Root size; (B) Root morphology.

\section{UnB 338}

This cultivar was selected from the progeny of the interspecific hybrid Manihot oligantha $\times$ cassava. It has high protein content, reaching $6 \%$ based on Kjeldahl analysis.

The roots also contain the essential amino acids tryptophan, arginine and methionine, which are normally not found or only at very low levels in cassava. It produces 1.5 - $2 \mathrm{~kg}$ roots per plant after one year, at a planting distance of $70 \times 70 \mathrm{~cm}, \mathrm{HCN}$ content ranges from $110-130 \mathrm{mg}$ per kilogram. It is used for flour production. Roots resist postharvest deterioration.

The progenitor root variety, ICB 300, has $4.5 \%$ protein (Nassar and Dorea, 1982). It is also used for flour production. The very high protein content of this cultivar indicates its potentiality for breeding more high protein content cultivars in future generations. The low productivity of roots is associated with the difficulty of stem cuttings germination. The latter character apparently came from the wild and is strongly associated with high protein content, probably due to a chromosome linkage that is difficult to break within a few generations. 
It is a shrub semi-erect, ca. 1.5 - $2 \mathrm{~m}$ (Figure 5). Leaves are membranaceous; fruits are prominently winged; roots are conical.
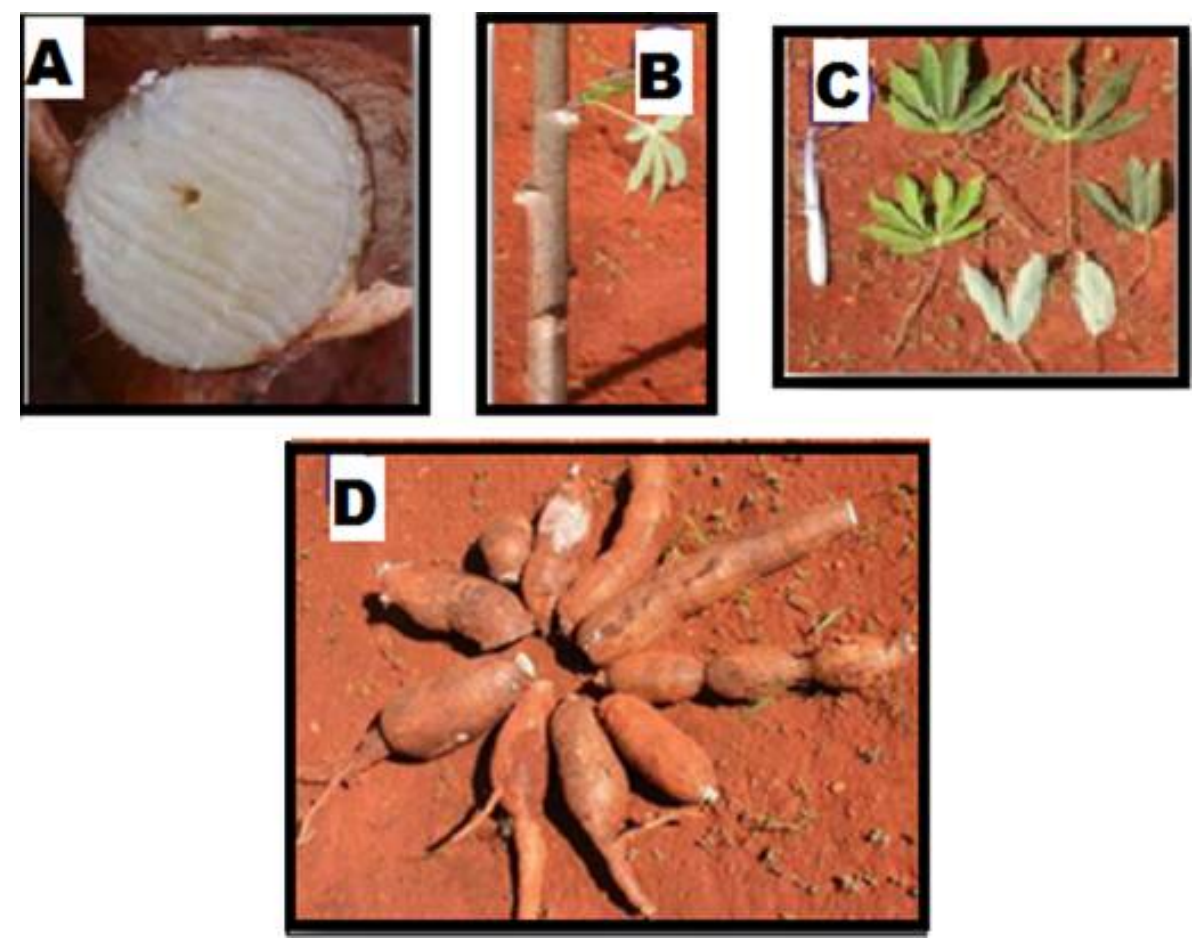

Figure 5. Cultivar UnB 338. (A) Root pulp with high protein and amino acid content; (B) Stem morphology; (C) Leaf morphology; (D) Root morphology.

\section{ICB 300}

An interspecific hybrid obtained by crossing cassava with the wild relative $M$. oligantha. It exhibits vigorous vegetative growth, apparently due to hybrid vigor. The most striking feature of this hybrid is its high protein content, reaching $4.5 \%$, compared to $1.5 \%$ in normal cassava. In addition, it is rich in amino acids not found in common cassava, these being arginine and lysine. It is used for consumption as flour. Root productivity is as high as $25 \mathrm{t} / \mathrm{ha}$ in moderately fertile soil. The only limitation of this cultivar is difficulty of stalk germination if propagation is undertaken after the rainy season begins. This characteristic apparently came from the wild parent.

It is a semi-erect to decumbent shrub, ca. $1.5-2.5 \mathrm{~m}$ tall; young stems are green (with moderate to strong petiole scars (Figure 6). Leaves are membranaceous and alternate; roots are long and cylindrical to conical and numerous, ca. $40-60 \mathrm{~cm}$ long and $3-4(-5) \mathrm{cm}$ in diameter, without a peduncle, have narrow constrictions, a darkbrown periderm, and a white cortex and pulp (Figure 6). 


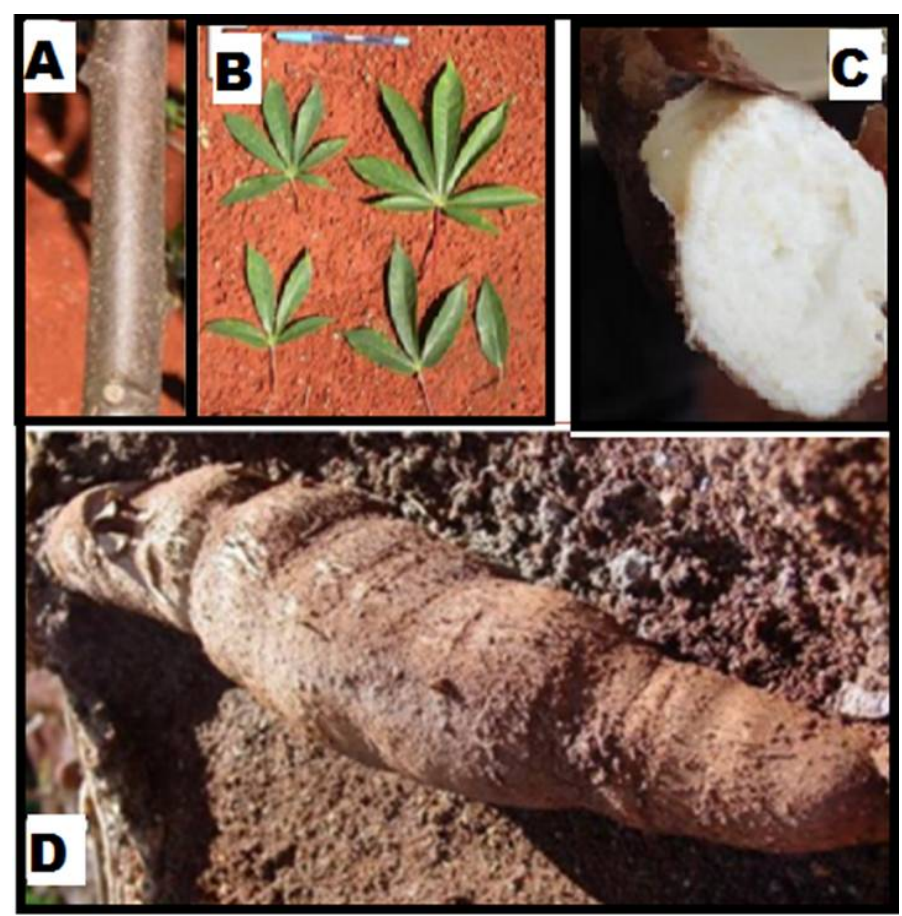

Figure 6. Cultivar ICB 300. (A) Stem morphology; (B) Leaf size and morphology; (C) Root pulp; (D) Root morphology.

\section{UnB 122}

This cultivar was selected from progeny of the interspecific hybrid Manihot anomala $\times$ cassava (Nassar, 1986; 1996; 2008). It produces $8-10 \mathrm{~kg}$ two years after planting at $70 \times 70 \mathrm{~cm}$. The root is used for flour consumption. It is tolerant to shade and grows very well in an agroforestry system co-cultivated with high shrubs (Nassar et al., 2010a).

It is a semi-erect to decumbent shrub, ca. $1.5-2 \mathrm{~m}$ tall (Figure 7). There is a single robust central stem at the base; sometimes there are two to three lateral stems that initiate $30-50$ $\mathrm{cm}$ from the base, $2.5-5 \mathrm{~cm}$ in diameter. Fruit is semiglobose, glabrous, with small spots of reddish pigmentation. Roots are long, cylindrical, and numerous (Figure 7), ca. 45 - $85 \mathrm{~cm}$ long and $3-9 \mathrm{~cm}$ in diameter, without a peduncle or constrictions.

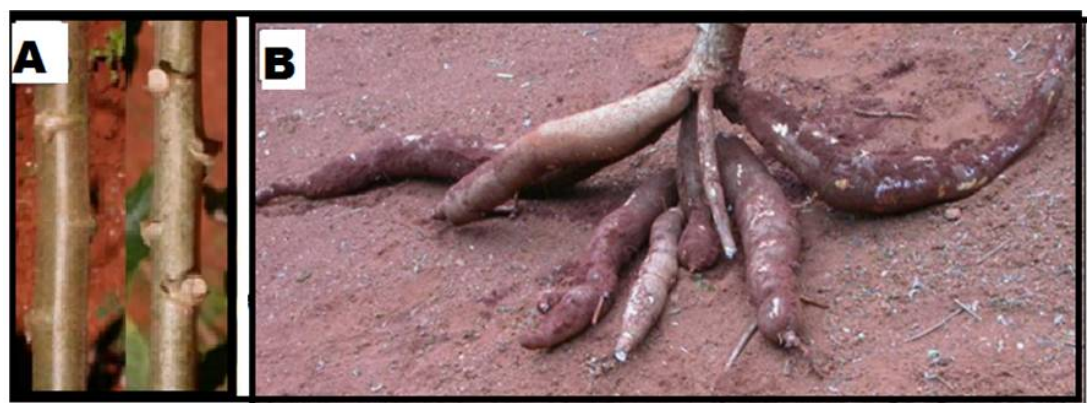

Figure 7. Cultivar UnB 122. (A) Stem morphology; (B) Root morphology. 


\section{UnB 110}

UnB 110 was selected form the progeny of an interspecific cassava hybrid with $M$. glaziovii (Nassar, 1996). It is productive of roots, reaching $8 \mathrm{~kg} / \mathrm{per}$ plant after two years under Brasilia conditions. This cultivar inherited resistance to the mealy bug, Phenacoccus manihoti from M. glaziovi. It also is resistant to bacterial infection by Xanthomas manihotis. This cultivar was released in 2009. It is a ca $3 \mathrm{~m}$ shrub (Figure 1A), and produces latex; the stem is glabrous with a diameter of $2-7 \mathrm{~cm}$. Young stems are purplish green and pubescent; leaves are membranaceous and alternate, palmately organized. Fruits have a large wing slightly undulated with purplish pigment. Roots are cylindrical, with and without a penduncle a light brown periderm, a cream-colored cortex and white pulp (Figure 8).

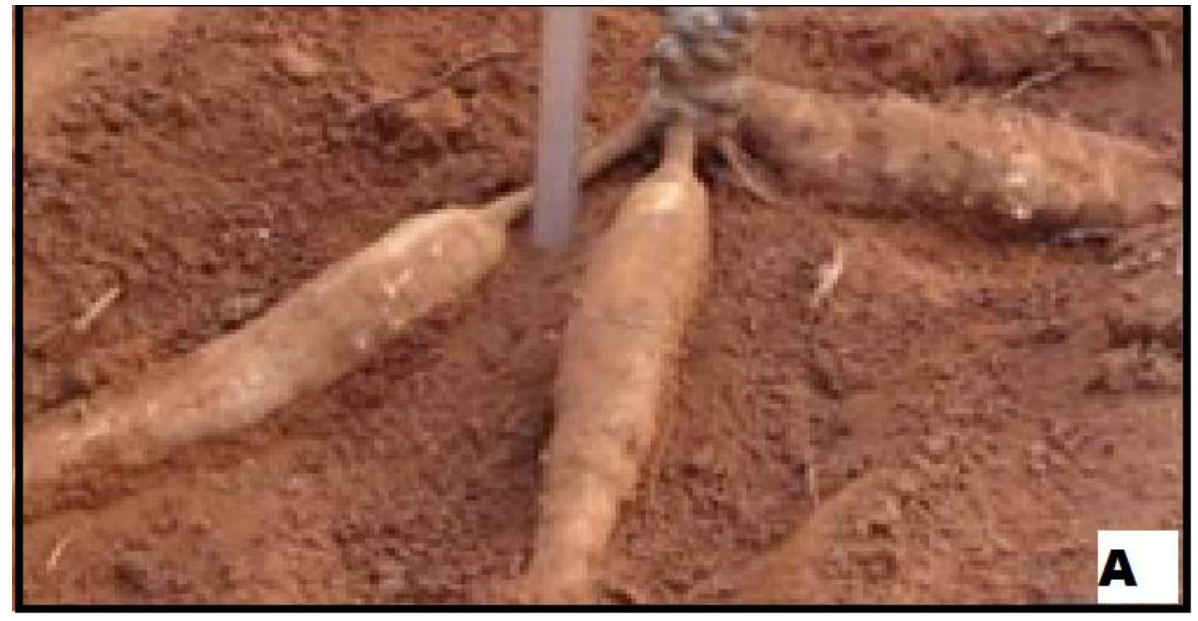

Figure 8. Cultivar UnB 110. (A) Root morphology.

\section{UnB 201}

UnB 201 is a cassava cultivar suitable to consume after cooking, with excellent palatability and few fibers in its peeled tuberous root. It was selected from indigenous cassava cultivars, followed by artificial chromosome duplication with colchicine resulting in $2 \mathrm{n}=72$. It contains about $3.6 \%$ protein compared to $1.3 \%$ in common varieties. It exhibits very low HCN contents (around $10-12 \mathrm{mg} / \mathrm{kg}$ ), coupled with excellent palatability (Nassar et al., 2009). It cooks very rapidly, in less than 20 minutes. It has a high betacarotene content of $7 \mathrm{mg}$ per $100 \mathrm{gm}$ (Nassar et al., 2007). Since FAO/WHO (1988) defines human daily requirements to be 2.2 to $5.1 \mathrm{mg}$, consuming daily $200 \mathrm{gm}$ of its cooked tuberous roots can suffice for human needs for this nutrient. This cultivar resists well in the field after six months of dry season in Brasilia and seems to be tolerant to borers due to its polyploid nature. It was released by the Universidade de Brasilia in 2009 and adopted since then by small-scale farmers in the Federal District and in the state of Goias. It is a compact shrub $2 \mathrm{~m}$ high (Figure 9), with dichomous branches, a glabrous stem, membranaceous leaves, and cylindrical and conical roots, without a peduncle that have a reddish-yellow pulp and are very soft when cooked. 


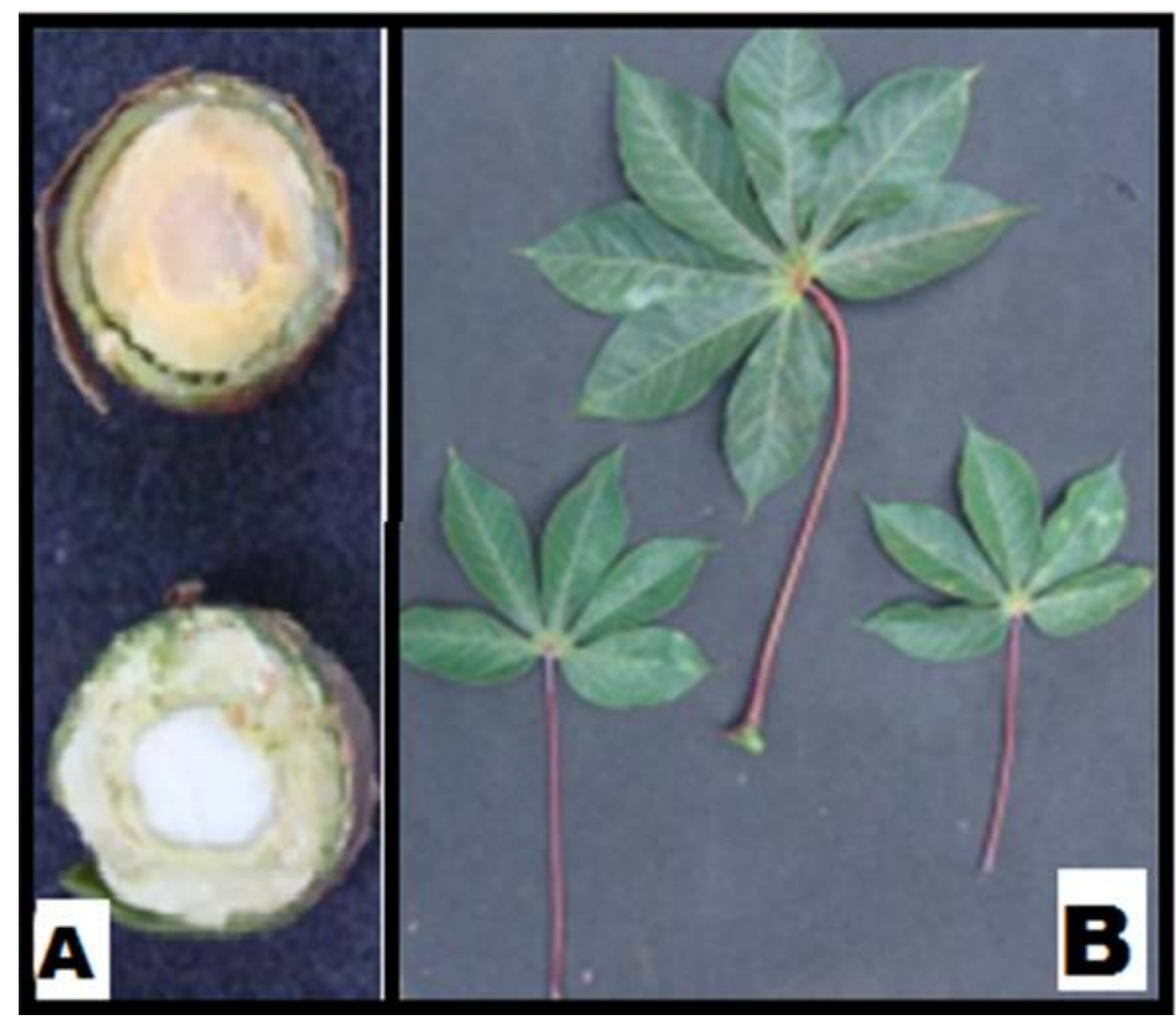

Figure 9. Cultivar UnB 201. (A) Above high carotene content, below common carotene content; (B) Leaf morphology.

\section{UnB 703}

This cultivar is a periclinal chimera (Nassar and Bomfim, 2013; Bomfim and Nassar, 2014). The epidermis is from M. esculenta, and internal tissues from Manihot fortalezensis. It is a very vigorous plant and is easily propagated vegetatively by cuttings. It produces huge edible cylindrical roots, reaching $14 \mathrm{~kg}$ per plant. This variety was synthesized experimentally by grafting rootstock $M$. fortalezensis with scions of $M$. esculenta cultivar UnB 032, followed by treating with a $10 \mathrm{ppm}$ naphthalene acetic acid solution for seven days to induce adventitious chimeral shoots in the fusion region between scion and stock (Nassar and Bomfim, 2013). This variety presents very vigorous growth, when compared to parents under the same conditions. It is composed of triploid internal tissues and a diploid epidermis. It is a vigorous semi-erect shrub ca. $4 \mathrm{~m}$ tall (Figure 10), with purplish green apical leaves, and apical branches, that are dichotomously and trichotomously branching. It has enlarged obovate lobed globose fruits with slender straight wings in whole fruits (Figure 10), with a peduncle forming a globe near the fruit. Tuberous cylindrical roots reach $90 \mathrm{~cm}$ long and about $5 \mathrm{~cm}$ in diameter (Figure 10), producing 14 - $18 \mathrm{~kg}$ per plant. 


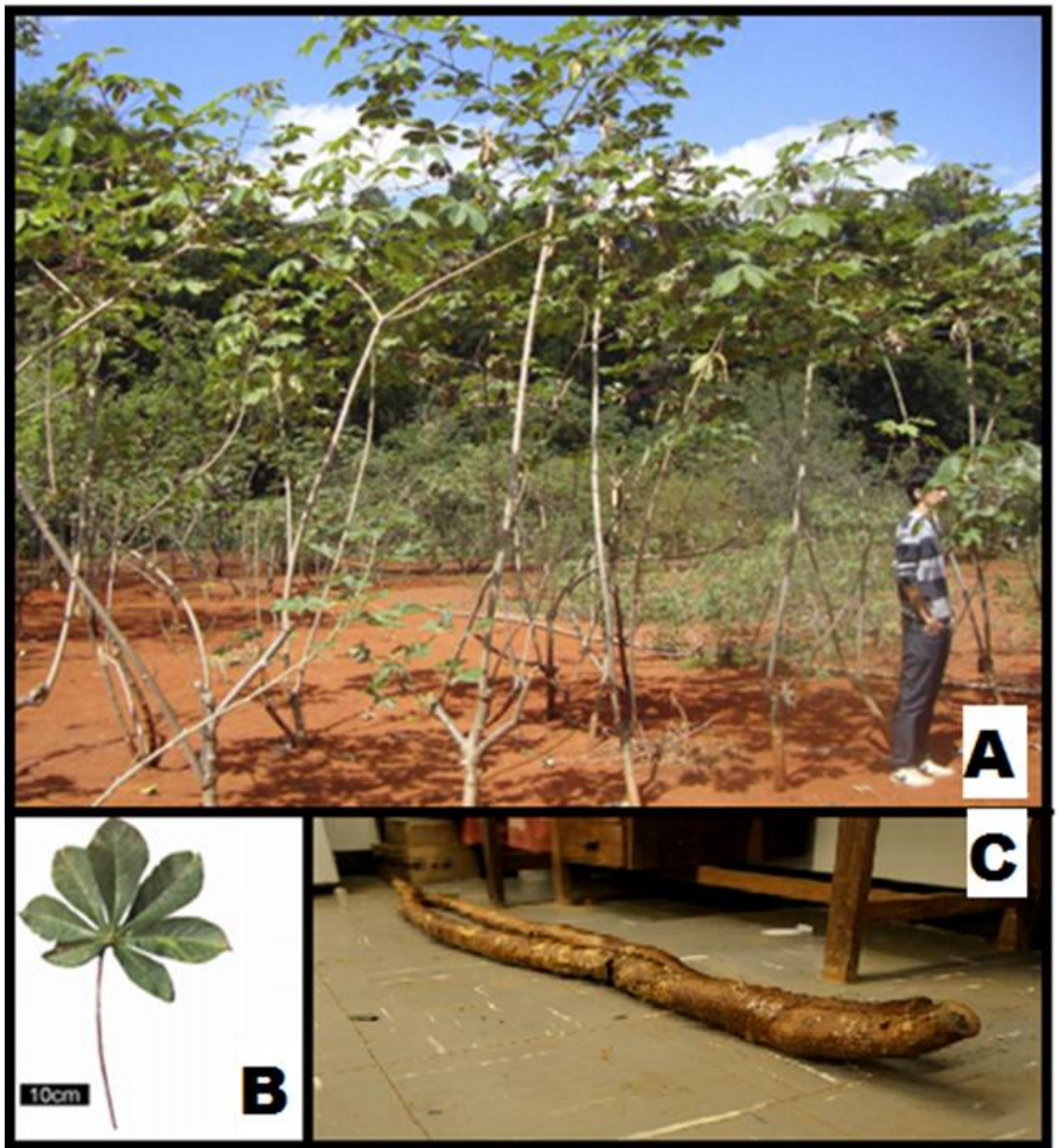

Figure 10. Cultivar 703. (A) Morphology of whole plants; (B) Leaf morphology and size; (C) Root size and morphology.

\section{ACKNOWLEDGMENTS}

The author wishes to express his gratefulness to CNPq for support over the years. The undergraduate students Thainara Siqueira and Larissa Miranda and Master's degree students Nayra Bomfim, Carla Freitas and Moyse Mendonca contributed in morphological description, typing and preparing text and photographs, to whom I am thankful. I am grateful too to the Canadian International Development Research Center (IDRC) for establishing the Manihot living collection at the Universidade de Brasilia.

\section{CONFLICTS OF INTEREST}

The authors declare no conflict of interest. 


\section{REFERENCES}

Bomfim NN and Nassar NMA (2014). Development of cassava periclinal chimera may boost production. Genet. Mol. Res. 13: 819-830

FAO/WHO (1988). Requirements of vitamin A, iron, foliate and vitamin B12. In: Vitamin and mineral requirements in human nutrition: Report of a joint FAO/WHO expert consultation. Expert Consultation on Human Vitamin and Mineral Requirements, Bangkok, Thailand, 21-30. 341 pp.

Nassar NMA (1977). Wild Manihot species of Central Brazil for cassava breeding. Can. J. Plant Sci. 58: 257-261.

Nassar NMA (1986). Genetic variation of wild Manihot species native to Brazil and its potential for cassava improvement. Field Crops Res. 13: 177-184.

Nassar NMA (1996). Development of cassava interspecific hybrids for savanna (Cerrado) conditions. J. Root Crops. 22: 9-17.

Nassar NMA (2008). Wild cassava confers useful characters upon the cultivation, transgenics cannot! J. Food Agric. Environ. 6: 554-555.

Nassar NMA, Abreu LFA, Teodoro D and Graciano D (2010a). Drought tolerant stem anatomy characteristics in Manihot esculenta (Euphorbiaceae) and a wild relative. Genet. Mol. Res. 9: 1023-1031.

Nassar NMA and Bomfim NN (2013). Synthesis of periclinal chimera in cassava. Genet. Mol. Res. 12: 610-617.

Nassar NMA and Collevatti R (2008). Embryonic, cytogenetic and molecular analysis of apomixis in cassava, Manihot esculenta Crantz. Gene Conserve. 7: 497-519.

Nassar NMA and Dorea JG (1982). Protein contents of cassava cultivars and its hybrid with manihot species. Turrialba. 32: 429-432.

Nassar NMA, Graciano-Ribeiro D, Bomfim N and Gomes PTC (2010b). Manihot fortalezensis Nassar, Ribeiro, Bomfim et Gomes: A new of Manihot from Ceará, Brazil. Genet. Resour. Crop Evol. 58: 831-835.

Nassar NMA, Nassar HN, Carvalho CG and Vieira C (1996). Induction of a productive aneuploid in cassava Manihot esculenta Crantz. Braz. J. Genet. 19: 123-125.

Nassar NMA and Ortiz R (2008) Cassava genetic resources: Manipulation for crop improvement. Plant Breed Rev. 31: 247-275.

Nassar NMA and Ortiz R (2010). Breeding Cassava to Feed the Poor. Sci. Am. 302: 78-82. DOI 84. 10.1038/scientificamerican0510-78.

Nassar NMA, Pires Júnior OR, Sousa MV and Ortiz R (2009). Improving carotenoids and amino-acids in Cassava. Recent Pat. Food Nutr. Agric. 1: 32-38.

Nassar NMA and Souza M (2007). Amino acid profile in cassava and its interspecific hybrid. Genet. Mol. Res. 6: 292297.

Nassar NMA, Vizzoto CS, Schwartz CA and Pires Júnior OR (2007). Cassava diversity in Brazil: the case of carotenoidrich landraces. Genet. Mol. Res. 6: 116-121.

Rogers DJ and Appan SG (1973). Manihot Manihotoides (Euphorbiaceae). Flora Neotropica. 13: 1-272.

Rogers DJ and Fleming HS (1973). Monograph of Manihot esculenta Crantz. Econ. Bot. 27: 1-114. 